\title{
Compound heterozygosity for two GHR missense mutations in a patient affected by Laron Syndrome: a case report
}

\author{
Stefania Moia ${ }^{1}$, Daniele Tessaris ${ }^{2}$, Silvia Einaudi ${ }^{2}$, Luisa de Sanctis², Gianni Bona' ${ }^{1}$, Simonetta Bellone ${ }^{1}$ \\ and Flavia Prodam ${ }^{1,3^{*}}$
}

\begin{abstract}
Background: Mutations localized in the Growth Hormone Receptor (GHR) gene are often associated with the pathogenesis of Laron Syndrome, an autosomal recessive hereditary disorder characterized by severe growth retardation. Biochemically, patients present normal to high circulating GH levels, in presence of very low or undetectable IGF-I levels, which do not rise after rhGH treatment.

Case presentation: We describe the case of a 3.8 years old girl with symmetrical short stature (-3.76 SDS), Iow IGF-1 and IGFBP-3, in presence of normal GH levels. Parents were not relatives and there was no family history of short stature. During the second day of birth, she developed severe hypoglycaemia that required glucose infusion. She presented frontal bossing and depressed nasal bridge. IGF-1 generation test showed no response, suggesting a GH resistance evidence. In the hypothesis of Laron Syndrome, we decided to perform a molecular analysis of Growth Hormone Receptor (GHR) gene. This analysis demonstrated that the patient was compound heterozygote for two missense mutations.

Conclusions: GHR gene mutations are a well demonstrated cause of GH insensitivity. In heterozygous patients, probably the normal stature may be achieved by a compensatory mechanism of GH secretion or signalling. On the contrary, in homozygous or compound heterozygous patients these compensatory mechanisms are inadequate, and short stature may be the consequence.
\end{abstract}

Keywords: Growth Hormone, Growth Hormone Receptor, Laron Syndrome, Short Stature

\section{Background}

The Growth Hormone Receptor (GHR) is a type I transmembrane glycoprotein that belongs to the cytokine receptor superfamily [1]. The human gene maps to chromosome 5p13.1-p12 and is composed by 10 exons, with exon 1 and a large part of exon 10 that are untranslated regions and most of exon 2 that encodes for the signal peptide [2, 3]. The signal peptide (residues 1-18) is later removed from the mature protein that contains 638 amino acids [4]. In particular, exon 2-7 of GHR gene encoded for the extracellular domain of the receptor, involved in $\mathrm{GH}$ hormone

\footnotetext{
* Correspondence: flavia.prodam@med.uniupo.it

${ }^{1}$ Division of Pediatrics, Department of Health Sciences, University of Piemonte Orientale, Novara, Italy

${ }^{3}$ Division of Endocrinology, Department of Translational Medicine, University of Piemonte Orientale, Novara, Italy

Full list of author information is available at the end of the article
}

binding, exon 8 for the transmembrane domain and exon 9-10 encoded for the cytoplasmic domain that activates the JAK-STAT signalling pathway $[5,6]$. GHR is expressed as a dimer on the cell surface, with a single GH molecule that binds two GHRs extracellular domains sequentially and induces a conformational change in the receptor, essential for signal transduction [7].

Defects in the GHR protein, resulting from abnormalities of the GHR gene, have been shown to result in the clinical phenotypes of classical Growth Hormone Insensitivity or Laron Syndrome [5, 8]. The first is clinically characterized by severe postnatal growth failure and facial dysmorphism, and biochemically by normal-to-elevated circulating $\mathrm{GH}$ concentrations but deficiencies in circulating Insulin-like Growth Factor 1 (IGF-1) and Insulin-like Growth Factor Binding Protein 3 (IGFBP-3) [9]. Laron 
Syndrome is an autosomal recessive hereditary disorder characterized by severe growth retardation (height -3 to -10 standard deviation score [SDS]), small cranium with underdeveloped facial bones, acromicria and organomicria, obesity and hypogenitalism. In addition, circulating $\mathrm{GH}$ levels are high in presence of low-to-undetectable IGF-I levels, which do not rise after short-term or longterm rhGH administration. The only treatment for Laron Syndrome is daily rhIGF-I administration [10].

In this report, we described a child referred to our Pediatric Endocrinology Department for a severe growth failure, in presence of low IGF-1 and IGFBP-3, but normal GH levels. After exclusion of a growth hormone deficiency condition, we performed direct sequencing of GHR gene sequence. This analysis demonstrated that the patient was compound heterozygote for two missense mutations. In particular, one of these mutations involved the first translation initiation codon of the protein. Consequently, the correct expression of the receptor will be most likely inhibited, probably causing the observed Laron phenotype.

\section{Case presentation}

We report a 3.8 years old girl who was referred to our Pediatric Endocrinology Department for short stature. At first evaluation she was 1.6 years old. She presented a symmetrical short stature: height was $72.5 \mathrm{~cm}(-2.58$ SDS), sitting height was $46.1 \mathrm{~cm}(-2.3 \mathrm{SDS})$, sitting height/height ratio was 0.63 (0 SDS), weight was $8.2 \mathrm{~kg}$ $(-3.15$ SDS $)$ and head circumference was $46.8 \mathrm{~cm}(+0.31$ SDS). She was prepuberal. Facial features included frontal bossing and depressed nasal bridge. No other congenital abnormalities were evident (Fig. 1). Subscapular skinfold was $18.4 \mathrm{~mm}$, tricipital skinfold $12.5 \mathrm{~mm}$.
She was born from a pregnancy of $36+5$ weeks characterized by gestational mellitus diabetes. Neonatal weight was $2900 \mathrm{~g}$ (AGA), length was $47.7 \mathrm{~cm}$ (AGA), head circumference was $33 \mathrm{~cm}$ (AGA) and Apgar score was $9 / 10$. During the second day of birth, she developed severe hypoglycaemia that required glucose infusion. Her father and mother are not related, with proportional and normal height: mother height is $162 \mathrm{~cm}$ whereas father height is $180 \mathrm{~cm}$ (target height $164.5 \mathrm{~cm}$ ). There are no cases of short stature in family members (only child). Parents' origin was from North of Italy and Sicily.

Biochemically, blood count, creatinine, liver function, electrolytes, urine evaluation and serological screening for celiac disease were normal. Her serum basal GH levels were $11.57 \mathrm{ng} / \mathrm{ml}$ with glucose levels of $59 \mathrm{mg} / \mathrm{dl}$, IGF-1 $19.1 \mathrm{ng} / \mathrm{ml}(-2.7 \mathrm{SDS})$ and IGFBP-3 $0.7 \mathrm{mcg} / \mathrm{ml}$ (2.0-4.5), respectively.

We failed to detect a positive response to the standard IGF-1 generation test by administering $0.033 \mathrm{mg} / \mathrm{kg} /$ day of rhGH for 4 consecutive days [IGF-1 d0: $13.6 \mathrm{ng} / \mathrm{ml}$ $(-2.6$ SDS); IGF-1 d4: $8.4 \mathrm{ng} / \mathrm{ml}$ (-2.8 SDS)], indicating a $\mathrm{GH}$ resistance.

Auxological follow-up for height is shown in Fig. 2.

At the age of 3.8 years old the height was $85.9 \mathrm{~cm}$ (-3.76 SDS), weight $11.9 \mathrm{~kg}(-2.42 \mathrm{SDS})$, head circumference $50 \mathrm{~cm}(0.52 \mathrm{SDS})$, and growth velocity deflected at $5.29 \mathrm{~cm} /$ year $(-1.80 \mathrm{SDS})$. Basal IGF-1 levels were $32 \mathrm{ng} / \mathrm{ml}(-2.28 \mathrm{SDS})$ and IGFBP-3 $0.8 \mathrm{mcg} / \mathrm{ml}(2.0-$ 4.5). After a high dose of rhGH $(2.8 \mathrm{mg} / \mathrm{mq} / \mathrm{die}: 1.6 \mathrm{mg} /$ die for 7 days), stimulated IGF-1 levels were $62.0 \mathrm{ng} / \mathrm{ml}$ $(-1.78 \mathrm{SDS})$ and IGF1BP-3 $0.9 \mathrm{mcg} / \mathrm{ml}(2.0-4.5)$. We decided to start rhIGF-1 (0.5 mg twice daily s.c.: $0.04 \mathrm{mg} /$ $\mathrm{kg} / \mathrm{twice}$ daily).
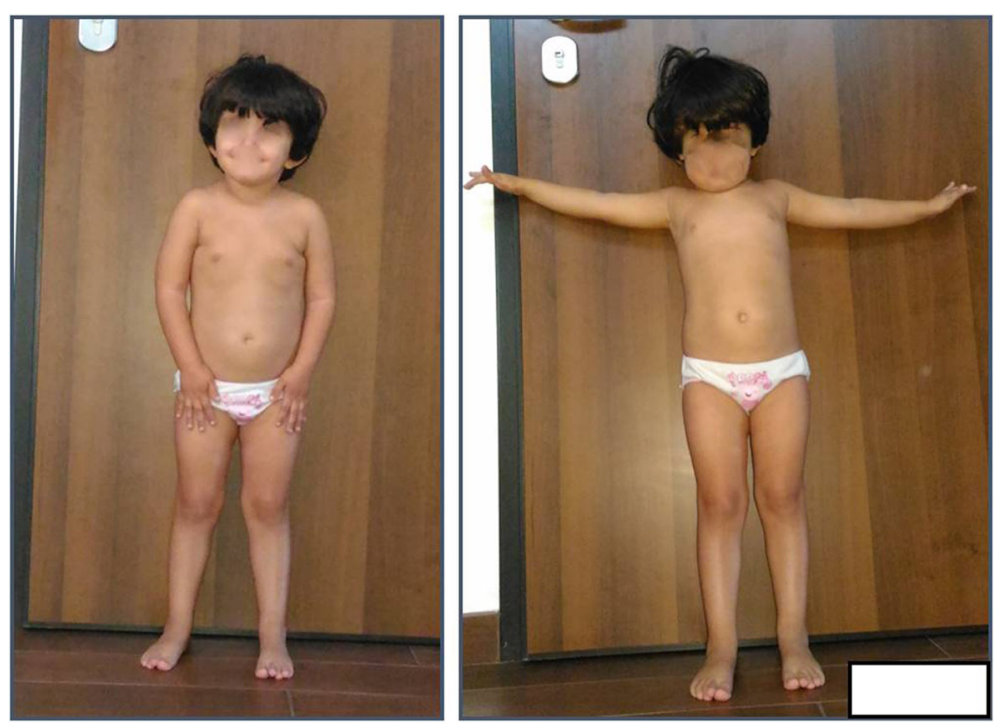

Fig. 1 Physical presentation at 3.8 years old 


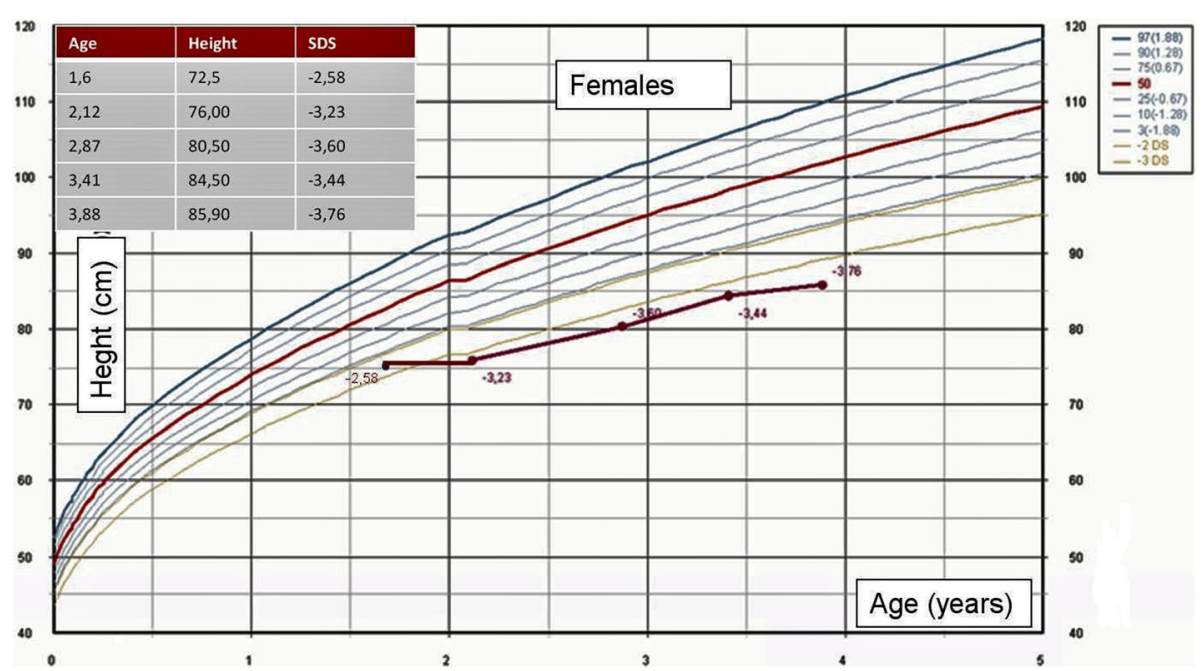

Fig. 2 Auxological follow-up - Females height for age WHO 2006

In the hypothesis of a case of Laron Syndrome, we performed the direct sequencing of the complete coding sequence of GHR gene that revealed the presence of two heterozygous variation. The first is a missense mutation caused by the transition adenine to guanine $(\mathrm{c} .1 \mathrm{~A}>\mathrm{G})$ in the first codon of exon 2. Given that, this substitution involved the translation initiation codon (Methionine) of the protein, the correct expression of the receptor will be necessary inhibited. The second variation is the substitution c.307G > A, that resulted in the replacement of the amino acid Aspartic Acid at position 103 to a residue of Asparagine (p.D103N), in exon 5 of the GHR sequence. This substitution involved the highly conserved Aspartic Acid 103 and, as predicted by the PolyPhen-2 Program (http://genetics.bwh.harvard.edu/pph2), it could be responsible for a damaging effect on GHR functionality. Due to the identification of these variations in her daughter, the parents underwent a molecular analysis for GHR gene mutation. The direct sequencing demonstrated that the father was heterozygous for the first codon mutation, whereas the mother was instead heterozygous for the p.D103N variation.

\section{Discussion and conclusions}

Heterozygous mutations in the GHR sequence have been frequently identified in children with idiopathic short stature, and these mutations should be taken into account when the other causes have been ruled out [11-13]. Laron Syndrome is a genetic disorder characterized by the inability to respond to endogenous or exogenous GH. This disorder is characterized by severe growth failure after birth, craniofacial disproportion, elevated serum GH and low/undetectable IGF-I levels that fail to respond to rhGH administration $[3,14]$.
In our patient, high doses of rhGH during IGF-1 generation tests demonstrated a partial response to IGF-1 production, that probably reflects the mild phenotype in her first years of life $[15,16]$. After the third year, due to the failure of compensatory mechanisms, her growth velocity deflected and short stature should require IGF-1 substitutive therapy to exceed GH partial insensitivity [10].

Molecular analysis of the GHR gene demonstrated the presence of the novel variation p.D103N, which involved the highly conserved residue of Aspartic Acid at position 103 of the extracellular domain. It is well demonstrated that most of the mutations identified in children with short stature were localized in the extracellular domain of the receptor, and are responsible of an impaired GH binding [12]. Considering that, the hormone binding and the subsequent receptor dimerization, are essential steps to activate the GHR signalling transduction, we can hypothesized that our p.D103N variation is responsible of an impaired $\mathrm{GH}$ binding that causes an altered receptor functionality.

The other mutation identified in our patient involved the first ATG codon of the GHR sequence that encodes for the Methionine necessary for the translation of all the mature proteins. Because the first ATG is essential for the initiation of the translation, this mutation certainly inhibits the correct expression of the receptor. A similar mutation was previously described by Quinteiro and co-workers, [17] in a patient with Laron Syndrome. They observed that the successive ATG codon is located in the sixth exon and encodes for the methionine at position 188. Even if this mutation could be able to start the receptor translation, the resulting protein will be truncated by the first 187 amino acids and will probably be not functional. 
It has been difficult to establish if the presence of a heterozygous mutation in the $\mathrm{GH}$ receptor can result in clinically significant GH insensitivity, except in the presence of a well-demonstrated dominantnegative effect. It can be assumed that, in patients who are heterozygous for a GHR mutation, the stature within the normal range may be achieved by a compensatory mechanism of GH secretion or signalling. On the contrary, homozygous or compound heterozygous patients would manifest a clinical GH insensitivity given that compensatory mechanisms are inadequate, and short stature may be the consequence [5].

\section{Abbreviations}

GH: Growth Hormone; GHR: Growth Hormone Receptor; IGF-1: Insulin-like Growth Factor 1; IGFBP-3: Insulin-like Growth Factor Binding Protein 3; JAKSTAT: Janus chinasi - Signal Transducer and Activator of Transcription; SDS: standard deviation score

\section{Acknowledgments}

The Authors wish to thank Professor Mara Giordano of the Laboratory of Genetics of Novara for her technical support.

\section{Funding}

This study was supported by the Cariplo Ricerca Biomedica 2009 Grant "Identificazione di geni coinvolti nel deficit di GH mediante ricerca di riarrangiamenti genomici sul cromosoma X" (PI: Professor Gianni Bona).

\section{Availability of data and materials}

Not applicable.

\section{Authors' contributions}

SM conducted the lab. Research; DT, SE, LdS and SB conducted the medical visits; SM, DT, and FP analysed the data and wrote the paper. GB revised the paper; FP had the primary responsibility for the final content. All authors read and approved the final manuscript.

\section{Ethics approval and consent to participate}

The diagnostic work-up and the treatment was discussed with the parents. An informed consent for all the procedures, including the genetic testing, was obtained only by parents due to the young age of the patient.

\section{Consent for publication}

Informed consent was obtained from the patient's parents for publication of this Case Report.

\section{Competing interests}

The authors declare that they have no competing interests.

\section{Publisher's Note}

Springer Nature remains neutral with regard to jurisdictional claims in published maps and institutional affiliations.

\section{Author details}

'Division of Pediatrics, Department of Health Sciences, University of Piemonte Orientale, Novara, Italy. ${ }^{2}$ Pediatric Endocrinology, Regina Margherita Children Hospital, University of Turin, Torino, Italy. ${ }^{3}$ Division of Endocrinology, Department of Translational Medicine, University of Piemonte Orientale, Novara, Italy.
Received: 14 July 2017 Accepted: 26 September 2017

Published online: 12 October 2017

\section{References}

1. Bazan JF. Structural design and molecular evolution of a cytokine receptor superfamily. Proc Natl Acad Sci U S A. 1990;87:6934-8.

2. Barton DE, Foellmer BE, Wood WI, Francke U. Chromosome mapping of the growth hormone receptor gene in man and mouse. Cytogenet Cell Genet. 1989:50:137-41

3. Laron Z. Laron syndrome (primary growth hormone resistance or insensitivity): the personal experience 1958-2003. J Clin Endocrinol Metab. 2004;89:1031-44.

4. Klammt J, Shen S, Kiess W, Kratzsch J, Stobbe H, Vogel M, et al. Clinical and biochemical consequences of an intragenic growth hormone receptor (GHR) deletion in a large Chinese pedigree. Clin Endocrinol. 2015:82:453-61.

5. Godowski PJ, Leung DW, Meacham LR, Galgani JP, Hellmiss R, Keret R, et al. Characterization of the human growth hormone receptor gene and demonstration of a partial gene deletion in two patients with Laron-type dwarfism. Proc Natl Acad Sci U S A. 1989;86:8083-7.

6. Fang P, Riedl S, Amselem S, Pratt KL, Little BM, Haeusler G, et al. Primary growth hormone $(\mathrm{GH})$ insensitivity and insulin-like growth factor deficiency caused by novel compound heterozygous mutations of the $\mathrm{GH}$ receptor gene: genetic and functional studies of simple and compound heterozygous states. J Clin Endocrinol Metab. 2007:92:2223-31.

7. Gent J, van Kerkhof P, Roza M, Bu G, Strous GJ. Ligand-independent growth hormone receptor dimerization occurs in the endoplasmic reticulum and is required for ubiquitin system-dependent endocytosis. Proc Natl Acad Sci U S A. 2002;99:9858-63.

8. Rosenfeld RG, Rosenbloom AL, Guevara-Aguirre J. Growth hormone (GH) insensitivity due to primary GH receptor deficiency. Endocr Rev. 1994;15: 369-90

9. Rosenbloom AL. Physiology and disorders of the growth hormone receptor (GHR) and GH-GHR signal transduction. Endocrine. 2000;12:107-19.

10. Laron Z. Emerging treatment options for patients with Laron syndrome. Expert Opin Orphan Drugs. 2014;2:681-94.

11. Rakover Y, Silbergeld A, Lavi I, Masalha R, Shlomo IB. Can exaggerated response to a $\mathrm{GH}$ provocative test identify patients with partial $\mathrm{GH}$ insensitivity syndrome? Eur J Endocrinol. 2002;146:319-23.

12. Bonioli E, Tarò M, Rosa CL, Citana A, Bertorelli R, Morcaldi G, et al. Heterozygous mutations of growth hormone receptor gene in children with idiopathic short stature. Growth Hormon IGF Res. 2005;15:405-10.

13. Goddard AD, Dowd P, Chernausek S, Geffner M, Gertner J, Hintz R, et al. Partial growth-hormone insensitivity: the role of growth-hormone receptor mutations in idiopathic short stature. J Pediatr. 1997:131:S51-5.

14. Rosenbloom AL. Growth hormone insensitivity: physiologic and genetic basis, phenotype, and treatment. J Pediatr. 1999:135:280-9.

15. Laron Z, Pertzelan A, Mannheimer S. Genetic pituitary dwarfism with high serum concentration of growth hormone - a new inborn error of metabolism? Isr J Med Sci. 1966;2:152-5.

16. Blair JC, Camacho-Hübner C, Miraki Moud F, Rosberg S, Burren C, Lim S, et al. Standard and low-dose IGF-I generation tests and spontaneous growth hormone secretion in children with idiopathic short stature. Clin Endocrinol. 2004:60:163-8

17. Quinteiro C, Castro-Feijoo L, Loidi L, Barreiro J, de la Fuente M, Dominguez $F$, et al. Novel mutation involving the translation initiation codon of the growth hormone receptor gene (GHR) in a patient with Laron syndrome. J Pediatr Endocrinol Metab. 2002;15:1041-5. 